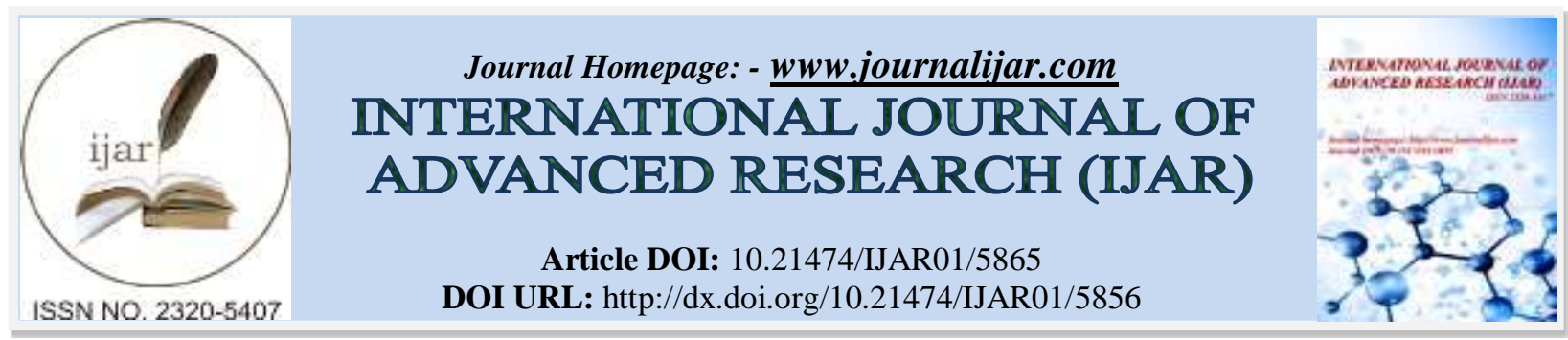

RESEARCH ARTICLE

\title{
EVALUATION OF DIFFERENT FERTILIZER SOURCES FOR THE MANAGEMENT OF AFLATOXIN CONTAMINATION IN GROUNDNUT (ARACHIS HYPOGAEA L.) IN THE SOUTHERN GUINEA SAVANNAH AGRO-ECOLOGICAL ZONE OF NIGERIA.
}

\author{
Eche C.O. ${ }^{1}$, Vabi. M. B ${ }^{2}$, Ekefan. E. $\mathbf{J}^{\mathbf{1}}$, Ajeigbe. H. A. ${ }^{2}$ and Ocholi F. $\mathbf{A}^{\mathbf{1}}$.
}

1. Plant Pathology Research Group, Department of Crop and Environmental Protection, Federal University of Agriculture, Makurdi, Benue State, Nigeria.

2. International Crops Research Institute for the Semi-Arid Tropics, Kano, Nigeria.

\section{Manuscript Info}

Manuscript History

Received: 14 September 2017

Final Accepted: 16 October 2017

Published: November 2017

Key words:-

Aflatoxin; Groundnut; Evaluation Fertilizers.

\section{Abstract}

Field experiments were conducted during 2016 and 2017 cropping seasons at the Teaching and Research Farms, Federal University of Agriculture, Makurdi, Nigeria. The experiments evaluated various combinations of Farmyard Manure (FYM), Gypsum, Single superphosphate (SSP) and NPK fertilizers applied at recommended rates. A total of eleven treatments were evaluated and included; FYM, Gypsum, SSP, NPK, FYM+Gypsum, FYM+SSP, FYM+NPK, Gypsum+SSP, Gypsum+NPK, SSP+NPK and Control. The experiments were laid-out in Randomized Complete Block Design (RCBD) with four replications. Enzyme Linked Immunosorbent Assay (ELISA) method was used to detect and quantify aflatoxin loads. Data collected included Plant Height and Number of Branches at 4, 8 and 12 weeks after planting, Number of Days to $50 \%$ Flowering and Yield (Fresh Pod, Dry Pod, and Haulms) and 100 Seed weight/plot. Data were subjected to Analysis of Variance and statistically significant differences were reported at $p<0.05$ using Fisher's Least Significant Difference. Findings from the study showed that the level of $\mathrm{AfB}_{1}$ contamination of groundnut by $\mathrm{AfB}_{1}$ was higher in 2017 compared to 2016. In both years however, plants grown in plots treated with FYM had the highest concentration of $\mathrm{AfB}_{1}(21.2 \mathrm{ppb}$ and $30.3 \mathrm{ppb})$ representing $28.4 \%$ and $32.1 \%$ increase over the untreated plots in 2016 and 2017, respectively. When FYM was combined with SSP, NPK and gypsum, $\mathrm{AfB}_{1}$ concentration was reduced by $18.4 \%, 26.5 \%$ and $50.3 \%$, respectively in 2017. These same trends were obtained in 2016. Application of only gypsum consistently reduced concentration levels of $\mathrm{AfB}_{1}$ the most. Contamination in groundnut grown on plots treated with only gypsum was reduced from $15.17 \mathrm{ppb}$ and $20.57 \mathrm{ppb}$ in the untreated plots in 2016 and 2017 respectively, to $3.76 \mathrm{ppb}$ and $5.7 \mathrm{ppb}$ representing over $70 \%$ reduction in both years. Although the use of FYM+NPK resulted in taller plants and higher haulm yield, SSP + NPK resulted in the highest pod yield in both years and were accompanied by higher levels of $\mathrm{AfB}_{1}$ concentrations in groundnut samples. The study concluded that the use of FYM should be discouraged in the cultivation of groundnut. Rather Gypsum + SSP or 
Gypsum + NPK should be promoted since their use was associated with reduced levels of aflatoxin contamination and better pod and haulm yields.

Copy Right, IJAR, 2017,. All rights reserved.

\section{Introduction:-}

Groundnut (Arachis hypogea L.) also known as peanut belongs to the Family Leguminoseae. It is an oil seed and food legume crop cultivated on approximately 25 million hectares worldwide with a production of 42.31 million metric tonnes (FAOStat, 2014). About 4-6\% of the total global production of groundnut is traded internationally, but most of the crop serve subsistence needs and are marketed domestically, often without entering any formal grain trading channels (Ntare et al., 2005). The plant is an annual crop, $25-50 \mathrm{~cm}$ high at maturity, with either spreading or bushy growth habit. It has a deep tap root system with numerous lateral roots endowed with good nodulation potentials (Uguru, 2011). Nigeria is the largest producer in Africa accounting for 30\% of total Africa's groundnut production pegged at 2,755,649 metric tons in 2014 (FAOStat, 2015). Though groundnut is produced in across Nigeria, production is concentrated in the nineteen States of the North namely: Kano, Katsina, Kaduna, Jigawa, Sokoto, Zamfara, Kebbi, Adamawa, Bauchi, Yobe, Borno, Benue, Plateau, Taraba, Nasarawa, Abuja, Kogi, Niger and Kwara (Ajeigbe et al., 2015).

Groundnut is an important component of the diets of most Nigerians, because of its high protein contents and carbohydrate contents (Ya'u, 2016). It is also rich in calcium, potassium, phosphorus, magnesium and vitamins B and E. Groundnut meal, a by-product of oil extraction, is an important ingredient in livestock feed. Groundnut haulms (stem and leaves) are very nutritious and widely used for feeding livestock across the drylands of West and Central Africa. According to Young (1996), oil extracted from groundnut is composed of mixed glycerides, and contains a high proportion of unsaturated fatty acids, in particular Oleic (50-56\%) and Linoleic (18-30\%) acids. The leaves are used in some West African countries as vegetable. Groundnut oil is the most important outcome of processing groundnut, which is used both for domestic and industrial purposes. About 75\% of the world's groundnut production is used in extraction of edible oil. With the recent thrust on bioenergy development, options are being explored to use groundnut as a bio-diesel crop, because the crop produces more oil per hectare than many other food crop ((Ya’u, 2016). In most, if not all countries of Sub-Saharan Africa, groundnut production, marketing and trade are important sources of employment, cash incomes and foreign exchange earners (Ntare et al., 2005). Nigeria mainly exports its nuts to Indonesia and countries of the European Union. However, groundnuts produced in SubSaharan Africa (SSA) are reported to be highly susceptible to attacks by the Aspergillus group of soil-borne fungi that produce toxic secondary metabolites known as aflatoxins (Payne, 1998).

The genus Aspergillus is a member of the phylum Ascomycota and comprises over 185 known species. Members of Aspergillus section Flavi are characterized by their ability to produce flavine-derived secondary metabolites which include aflatoxins. Aflatoxins are mycotoxins associated with hepatotoxicity, mutagenicity and carcinogenicity in human beings and cattle (Hesseltine, 1965; Ainsworth and Austwick, 1973). Species capable of producing aflatoxins include Aspergillus flavus, Aspergillus parasiticus, and several less common taxa such as Aspergillus nomius, Aspergillus tamarii, A. pseudotamarii, A. minisclerotigenes and A. bombycis (Cotty, 1994; Klich et al., 2009). Other Aspergillus outside of the section Flavi are also known to produce aflatoxins and species with this ability are known to be more diverse than previously thought (Cotty et al., 1999). Toxigenic strains of Aspergillus contaminate groundnuts and other crops along the value chain including post-harvest handling. Contamination varies from year to year and is particularly high when plants are exposed to stress toward the end of the growing season (Waliyar et al., 2015). Pre-harvest infections of aflatoxin usually occur when the plant is exposed to moisture and heat stress during pod development, when pods are damaged by insects or nematodes or when they are mechanically damaged during farm operations (Waliyar et al., 2007). As farming is primarily rain-fed in most countries of SSA, but also recognizing current climatic variability, conditions favouring the development of aflatoxin contamination occur more frequently. Hence the management of aflatoxin contamination in the face of climate change has become an increasing concern.

Quite a few approaches for the management of aflatoxin contamination have been reported. Cases for the use of aflatoxin resistant varieties (Upadhyaya et al., 2002; Nigam, 2004; Upadhyaya et al., 2004), use of biocontrol agents such as Trichoderma [T. viride (Tv 47), T. harzianum (Th 23), T. harzianum (Th 20), T. koningii (Tk 83)], geocarposphere bacterial strains of Pseudomonas [P. aeruginosa CDB35, P. cepacia and P. fluorescens] and Actinomycetes [strain CDA19)] in reducing groundnut seed colonization by competitive exclusion/inhabitation of 
Aspergillus species (Thakur and Waliyar, 2005) have also been advocated. Efforts are also being made to introduce 13S LOX (lipoxygenase) gene, which has been shown to deregulate aflatoxin production, and/or RNAi technology to knock-out 9S Lox gene that enhances the sporulation and aflatoxin production in groundnut (Anjaiah et al., 2006; Hameeda et al., 2006; Sharma et al., 2006). The use of soil amendments techniques such as gypsum, and cereal crop residues applied either singly or in various combinations at different cropping stages have also been reported (Waliyar et al., 2006). The advent of readily available fertilizers has brought about the reduction or termination of many pathogenic diseases through improved plant resistance, disease escape, altered pathogenicity, or microbial interactions (Alenyorege et al., 2015). Since aflatoxin resistant varieties, biocontrol agents and transgenic plants are not readily available to farmers with limited resource endowments in Nigeria, efficient fertility programs can indirectly enhance groundnut resistance to toxigenic strains of Aspergillus by reducing the impact of environmental stress, and increasing the quality of groundnut and groundnut-based products. This is the hypothesis upon which this study was conducted. The objectives of these trials were (i) to determine the effects of various combinations of Farmyard Manure (FYM) and inorganic fertilizers on aflatoxin contamination in the Southern Guinea Savannah, of Nigeria alongside while assessing the agronomic performance of SAMNUT 24; a recently released groundnut variety which is extra early maturing, high yielding, rosette resistant and market/farmer preferred (FMARD, 2014).

\section{Materials and Methods:- Experimental Site:-}

Two experiments were conducted, each during the 2016 and 2017 cropping seasons at the Teaching and Research Farms, Federal University of Agriculture, Makurdi located at latitude $07^{\circ} 45^{\prime} \mathrm{N}$ to $07^{\circ} 50^{\prime} \mathrm{N}$, longitude $08^{\circ} 45^{\prime} \mathrm{E}$ to $08^{\circ} 50^{\prime} \mathrm{E}, 98 \mathrm{~m}$ above sea level. The site falls within the Southern Guinea Savannah agro-ecological zone of Nigeria where the rainfall is bi-modally distributed with the highest peak in July/August. The raining season commences between March/April and terminates in October/November. The total annual rainfall is about 2000-2500 mm and maximum and minimum temperatures of $37^{\circ} \mathrm{C}$ and $21^{\circ} \mathrm{C}$, respectively, while the relative humidity is about $70-80 \%$. The land used was previously under intercropping with cassava (Manihot esculenta) and maize (Zea mays L.). The surface soil (0-15 cm depth) was characteristic loamy sandy with $80.8 \%$ sand, $8.2 \%$ silt and $11.0 \%$ clay contents. The soil $\mathrm{pH}$ (soil: $\mathrm{H}_{2} \mathrm{O}$ ) was 6.01 and contained $1.09 \%$ organic carbon, $0.09 \%$ total $\mathrm{N}, 8.70 \mathrm{mg} / \mathrm{kg}$ available $\mathrm{P}$, while $\mathrm{Ca}, \mathrm{Mg}, \mathrm{K}$ and $\mathrm{Na}$ contents were $3.79,1.3,0.06$ and $0.12 \mathrm{cmol} / \mathrm{kg}$, respectively. The ECEC of the soil sample was $6.68 \mathrm{cmol} / \mathrm{kg}$, exchangeable acidity $0.36 \mathrm{cmol} / \mathrm{kg}$ and base saturation was $20.0 \%$. The nutrient profile of the farmyard manure used was $69.2 \%$ organic carbon, $5.2 \%$ total $\mathrm{N}, 37 \mathrm{mg} / \mathrm{kg}$ available $\mathrm{P}$, while calcium, magnesium, potassium and sodium concentrations were $4.8,3.0,0.17$ and $0.10 \mathrm{cmol} / \mathrm{kg}$, respectively. The ECEC and base saturation of the manure were $19.2 \mathrm{cmol} / \mathrm{kg}$ and $40 \%$, respectively respectively.

\section{Experimental Design:-}

The experiment evaluated various combinations of organic [Farmyard manure (FYM)] and inorganic [Gypsum, Single superphosphate (SSP) and NPK (15:15:15)] fertilizers applied at recommended rates. Farmyard manure was applied at the rate of 5 tons/ha while Gypsum, SSP and NPK were applied at 2.24 tonsha $^{-1}, 60 \mathrm{~kg} \mathrm{P}_{2} \mathrm{O}_{5}$ and and 120 $\mathrm{kg} \mathrm{NPK} \mathrm{kgha}^{-1}$ respectively. A total of eleven treatments were used in the experiment and included; FYM, Gypsum, SSP, NPK, FYM+Gypsum, FYM+SSP, FYM+NPK, Gypsum+SSP, Gypsum+NPK, SSP+NPK and Control (untreated plots). The experiments in both 2016 and 2017 were laid-out in Randomized Complete Block Design (RCBD) with four replications of $79 \mathrm{~m} \times 26 \mathrm{~m}\left(2054 \mathrm{~m}^{2}\right)$ with plot sizes of $5 \mathrm{~m} \mathrm{x} 4 \mathrm{~m}\left(20 \mathrm{~m}^{2}\right)$. The experimental site was cleared and cultivated manually. Farmyard manure was incorporated into randomly selected plots two weeks before planting while other inorganic fertilizers were applied two weeks after planting (WAP). The groundnut seeds (SAMNUT 24) were sown at a spacing of $10 \mathrm{~cm}$ within rows and $75 \mathrm{~cm}$ between rows, planting two seeds per hole. Weeding was carried-out at 3,6 and 9 WAP.

\section{Enzyme Linked Immunosorbent Assay (ELISA):- Sample Extraction:-}

One hundred grams of groundnut seeds were collected from each treatment and blended separately each time, thoroughly washing and rising the blender with sodium hypochlorite $(\mathrm{NaOCl})$ to avoid cross contamination. Twenty $(20 \mathrm{~g})$ of each of the blended groundnut seeds were ground into fine powder and triturated with $100 \mathrm{ml}$ of $70 \%$ methanol (v/v $70 \mathrm{ml}$ absolute methanol in $30 \mathrm{ml}$ distilled water) containing $5 \mathrm{~g}$ potassium chloride in Waring Commercial blender up until homogeneity was reached. The extract was transferred into a $250 \mathrm{ml}$ of properly labelled conical flasks and shaken on a Benchamark orbital (Model ORBI-Shaker) shaker for 30 minutes. Filtration was done using Whatman filter paper number 41 and the sample was later diluted in 1:10 phosphate buffer saline in 
Tween-20 (1 ml of extract and $9 \mathrm{ml}$ of buffer). The setup was left standing for 10 hours after which analysis of each sample began.

\section{Sample Analysis:-}

$\mathrm{AFB}_{1}$-BSA antigen was coated unto an ELISA plate. Specific antibodies available in the sample or standard competed with the bound $\mathrm{AFB}_{1}-\mathrm{BSA}$ antigen with the help of immune-globulins. Para Nitrophenylphosphate substrate was added which helped in colour development. $\mathrm{AFB}_{1}$ levels were quantified using a spectrophotometer by giving optical density values at a $405 \mathrm{~nm}$ wavelength. Linear regression curve was plotted for optical density values and a standard curve was extrapolated with a known correlation coefficient thereby giving $\mathrm{AFB}_{1}$ concentrations in parts per billion.

\section{Data Collection:-}

Agronomic data collected included Plant Height at 4, 8 and 12 WAP measured in centimeters, Number of Branches at 4, 8 and 12 WAP, Number of Days to $50 \%$ Flowering, Fodder Weight/plot (g), Fresh Pod Weight/plot (g), Dry Pod Weight/plot (g) and 100 Seed weight/plot (g). Meteorological data for 2016 and 2017 Cropping Seasons were obtained from the Nigerian Meteorology Headquarter, Tactical Command, Makurdi Airport, Benue State, Nigeria as shown in Table 1.

\section{Data Analysis:-}

Agronomic data were subjected to analysis of variance using GenStat $17^{\text {th }}$ Edition (VSN International Ltd, 2014) software. Statistically significant differences were reported at $\mathrm{p}<0.05$. If the overall F-test was significant $(\mathrm{p}<$ 0.05), then Fisher's Least Significant Difference (LSD) test was used to compute the smallest significant difference between two means.

Table 1:- Meteorological Data of Makurdi, Benue State Nigerian Meteorological Agency (NiMet)

\begin{tabular}{|c|c|c|c|c|c|}
\hline \multirow[t]{3}{*}{ Month } & \multirow[t]{3}{*}{ Rainfall (mm) } & \multicolumn{2}{|c|}{ Temperature $\left({ }^{\circ} \mathrm{C}\right)$} & \multicolumn{2}{|c|}{ Relative Humidity (\%) } \\
\hline & & Maximum & Minimum & Maximum & Minimum \\
\hline & & \multicolumn{2}{|c|}{2016} & & \\
\hline April & 26.4 & 31.1 & 26.2 & 38 & 32 \\
\hline May & 38.4 & 28.6 & 24.0 & 52 & 30 \\
\hline June & 100.4 & 28.4 & 24.0 & 86 & 69 \\
\hline July & 126.6 & 27.0 & 23.5 & 76 & 74 \\
\hline August & 238.8 & 35.6 & 23.2 & 93 & 76 \\
\hline September & 139.3 & 30.2 & 23.3 & 84 & 73 \\
\hline \multirow[t]{2}{*}{ Average (Total) } & 111.7 & 30.2 & 24.0 & 71.5 & 59.0 \\
\hline & & \multicolumn{2}{|c|}{2017} & & \\
\hline April & 28.4 & 35.2 & 23.1 & 29 & 26 \\
\hline May & 55.8 & 33.1 & 22.3 & 59 & 38 \\
\hline June & 120.0 & 34.6 & 21.6 & 81 & 65 \\
\hline July & 224.5 & 30.1 & 22.5 & 95 & 75 \\
\hline August & 383.6 & 37.3 & 22.0 & 94 & 80 \\
\hline September & 312.6 & 33.2 & 22.0 & 96 & 70 \\
\hline Average (Total) & 187.5 & 33.9 & 22.3 & 75.7 & 59.0 \\
\hline
\end{tabular}

\section{Results:-}

\section{Effect of Fertilizer Combinations on Mean Levels of $\mathrm{AfB}_{1}$ :-}

The mean aflatoxin $B_{1}\left(A_{f} B_{1}\right)$ concentrations of groundnut grown under different fertilization regimes in 2016 and 2017 are presented in Figures 1 and 2. The results showed that $\mathrm{AfB}_{1}$ ranged from $3.76 \mathrm{ppb}$ to $21.2 \mathrm{ppb}$, and $5.7 \mathrm{ppb}$ to $30.3 \mathrm{ppb}$ in 2016 and 2017, respectively. The level of contamination of groundnut by $\mathrm{AfB}_{1}$ was generally higher in 2017. In both years however, kernels from plants grown in plots treated with FYM had the highest concentration of $\mathrm{AfB}_{1}(21.2 \mathrm{ppb}$ and $30.3 \mathrm{ppb}$ ) representing $28.4 \%$ and $32.1 \%$ increase over the untreated plots in 2016 and 2017, respectively. In 2016, there was a reduction in $\mathrm{AfB}_{1}$ concentrations when FYM was combined with SSP, NPK and gypsum by $65.5 \%, 44.3 \%$ and $59.4 \%$ respectively; similar results were obtained in 2017. A combination of FYM with SSP, NPK and gypsum, resulted in $18.4 \%, 26.5 \%$ and $50.3 \%$ resulting in a reduction in $\mathrm{AfB}_{1}$ concentrations, respectively. 
The application of gypsum consistently reduced concentration levels of $\mathrm{AfB}_{1}$ when applied solely or in combination with NPK or SSP. When compared to the untreated plot, contamination in groundnut grown on gypsum-solely treated plots was reduced from $15.17 \mathrm{ppb}$ and $20.57 \mathrm{ppb}$ in the untreated plots in 2016 and 2017 respectively, to 3.76 $\mathrm{ppb}$ and $5.7 \mathrm{ppb}$ representing over $70 \%$ reduction in both years.

\section{Effect of Fertilizer Combinations on Growth of Groundnut:-}

Table 2 shows the effects of different fertilizer combinations on groundnut Plant Height, Number of Branches and Days to $50 \%$ flowering in 2016 and 2017. Treatment effect was statistically significant $(\mathrm{p}<0.05)$ for Plant Height and Number of Branches. Days to $50 \%$ flowering was not statistically significant $(\mathrm{p}>0.05)$. Groundnut plants grown on plots treated with FYM+NPK were consistently the tallest with a percentage difference of $35.3 \%$ and 45.3\% over plants grown on the treated plots. In both years, however, plants grown on plots treated with NPK (69.8 $\mathrm{cm}$ and $77.4 \mathrm{~cm})$, Gypsum + NPK $(71.5 \mathrm{~cm}$ and $79.9 \mathrm{~cm})$ and SSP + NPK $(70.2 \mathrm{~cm}$ and $75.5 \mathrm{~cm})$ were taller and had values above the grand mean of $63.7 \mathrm{~cm}$ and $70.7 \mathrm{~cm}$ in 2016 and 2017 respectively. The effects of FYM + Gypsum and FYM+SSP on groundnut Plant Height were not consistent in both years. The number of Branches was also consistently highest in plants grown on plots treated with FYM + NPK in 2016 and 2017 with a percentage difference of $51.6 \%$ and $37.4 \%$ over plants grown on the untreated plots. Plants grown on plots treated with NPK, FYM + Gypsum and SSP + NPK had higher Number of Branches above the grand mean value

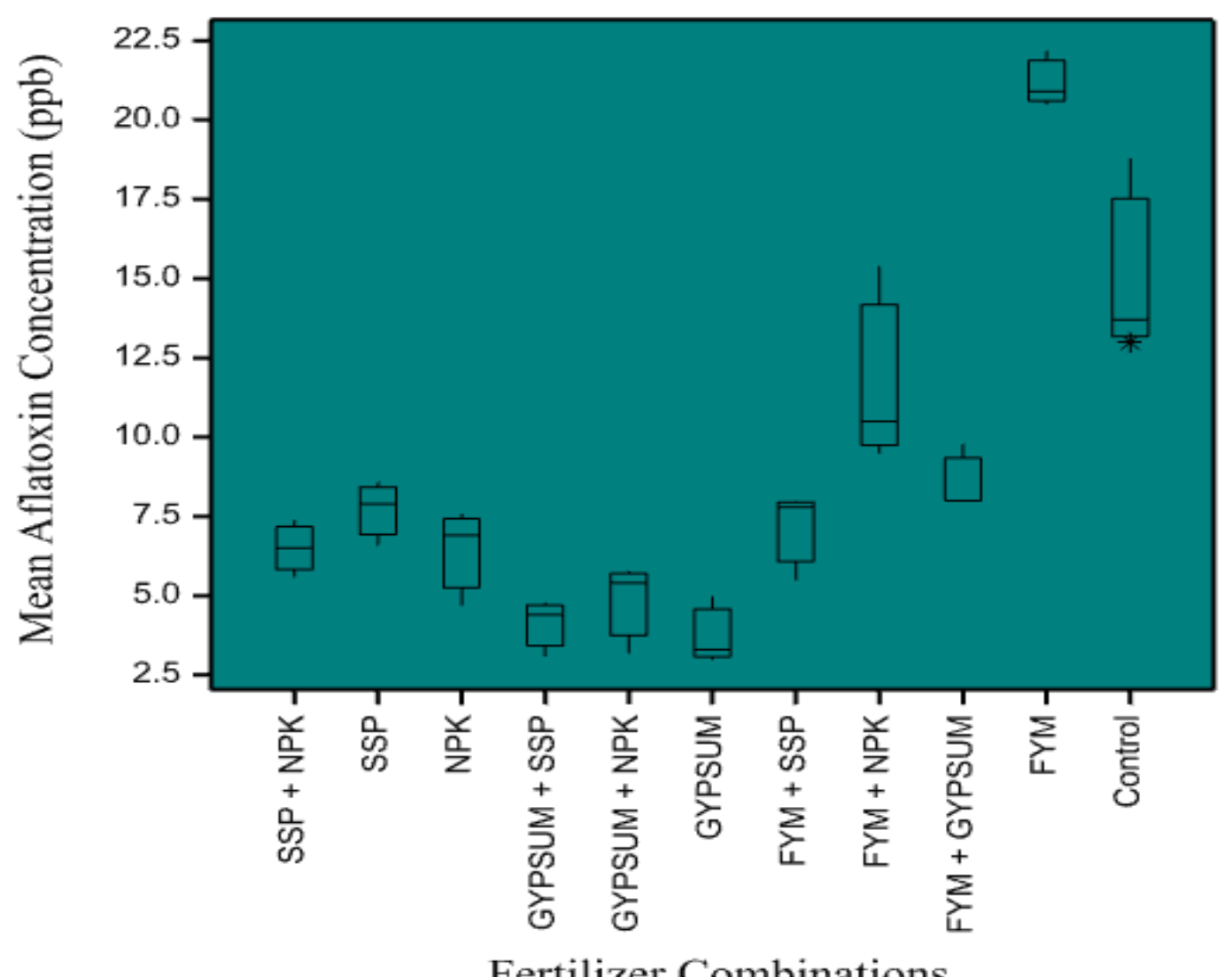

Figure 1:- Mean aflatoxin levels of groundnut grown under soils treated with difference combinations of fertilizers in 2016 


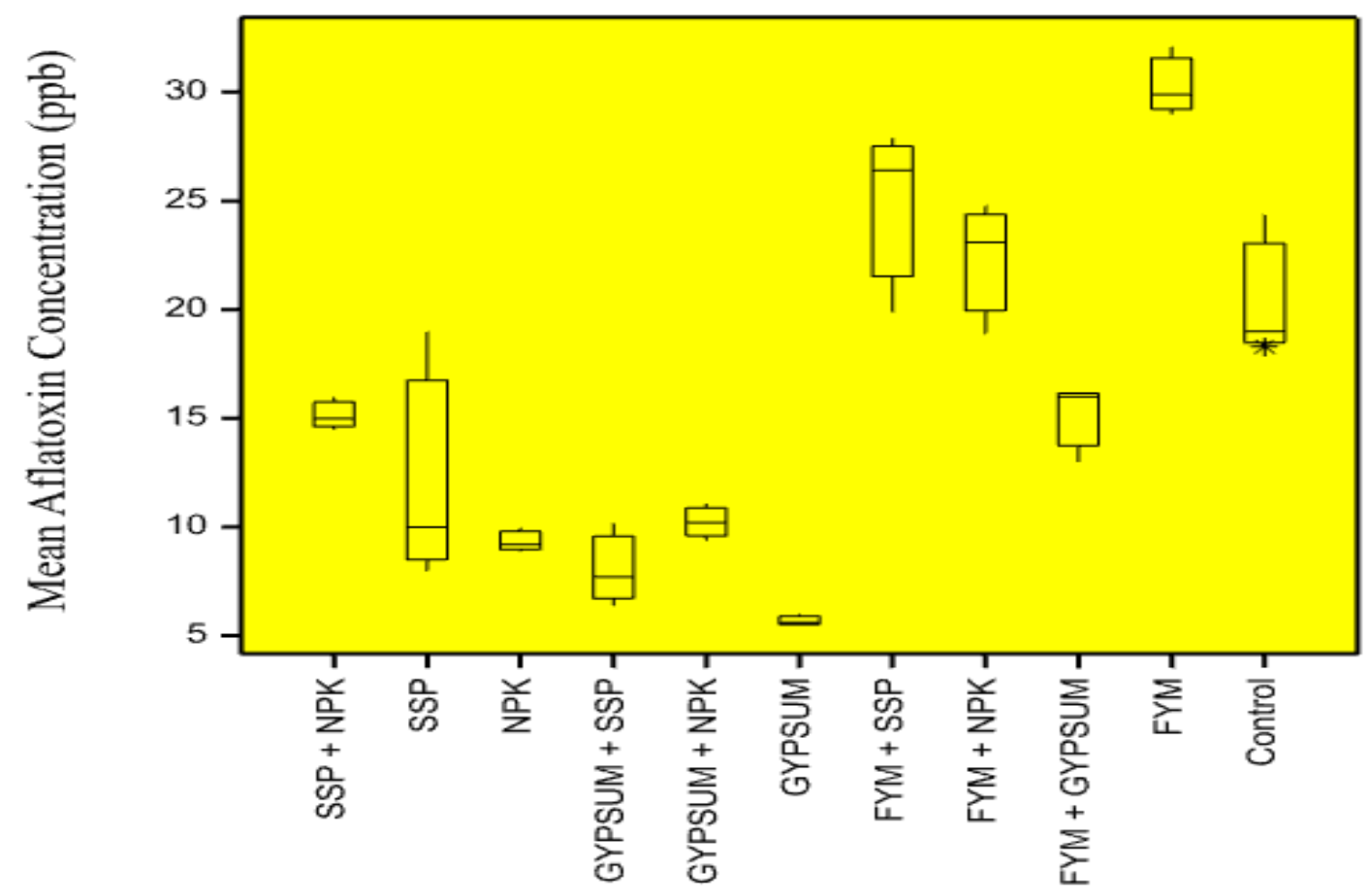

Fertilizer Combinations

Figure 2:- Mean aflatoxin levels of groundnut grown under soils treated with difference combinations of fertilizers in 2017

\section{Effect of Fertilizer Combinations on Yield Groundnut:-}

The effects of fertilizer combinations on groundnut Fresh Pod Yield, Dry Pod Yield, Haulm Yield and 100 Seed Weight are presented in Table 3. Treatment effect was statistically significant for all parameters except 100 Seed Weight. Groundnut plants grown on plots treated with SSP + NPK consistently had the highest Fresh Pod Yield (1.46 t/ha and $1.71 \mathrm{t} / \mathrm{ha})$ and Dry Pod Yield (1.64 t/ha and $1.66 \mathrm{t} / \mathrm{ha})$ in 2016 and 2017. The least Fresh and dry pod yields were recorded on plants grown on the untreated plots. Plants grown on plots treated with FYM + SSP outperformed the remaining fertilizer treatments in terms of Fresh Pod Yield (1.44 t/ha and 1.65 t/ha), Dry Pod Yield (1.38 t/ha and $1.56 \mathrm{t} / \mathrm{ha}$ ) in 2016 and 2017. Plots treated with FYM and Gypsum + SSP had fresh pod yield values which were above the grand mean (1.30 t/ha) in 2016. In 2017 however, plots treated with FYM, SSP, NPK and Gypsum + SSP had higher fresh pod yield values above the grand mean $(1.51 \mathrm{t} / \mathrm{ha})$.

Haulm Yield was generally higher in 2017 compared to the yield of each fertilizer combination evaluated in 2016. Groundnut plants grown on plots treated with FYM + NPK had the highest haulm yield of $2.42 \mathrm{t} / \mathrm{ha}$ and $4.78 \mathrm{t} / \mathrm{ha}$ in 2016 and 2017, respectively. Haulm yields in both years were the least obtained in plants grown on the untreated plots. In 2016, plots treated with FYM, NPK, FYM+ SSP, Gypsum + NPK, SSP + NPK gave higher haulm yield representing $36.4 \%, 26.9 \%, 42.4 \%, 44.8 \%$ and $36.9 \%$ respectively over the untreated plots. Also, plots treated with FYM, NPK, FYM+ SSP, Gypsum + NPK, SSP + NPK gave higher yields above the grand mean representing $51.6 \%, 46.6 \%, 52.9 \%, 49.9 \%$ and $49.9 \%$ respectively, over the untreated plots. 
Table 2:- Effect of Different Fertilizer Sources and Combinations on Growth of Groundnut in 2016 and 2017

\begin{tabular}{|l|c|c|c|c|c|c|c|}
\hline Fertilizer Combination & \multicolumn{2}{c|}{$\begin{array}{c}\text { Plant Height at } \\
\text { 12 WAP (cm) }\end{array}$} & \multicolumn{2}{c|}{$\begin{array}{c}\text { Number of Branches } \\
\text { at }\end{array}$} & \multicolumn{2}{l|}{ Days to 50 \% Flowering } \\
\hline & 2016 & 2017 & 2016 & 2017 & 2016 & 2017 \\
\hline FYM & 62.4 & 69.9 & 8.1 & 10.1 & 36.7 & 35.2 \\
\hline GYPSUM & 58.5 & 61.2 & 7.8 & 9.1 & 36.6 & 36.7 \\
\hline SSP & 58.0 & 57.7 & 8.1 & 9.7 & 36.3 & 34.8 \\
\hline NPK & 69.8 & 77.4 & 10.6 & 12.6 & 36.7 & 34.5 \\
\hline FYM + GYPSUM & 60.5 & 70.8 & 10.1 & 11.0 & 36.7 & 34.7 \\
\hline FYM+SSP & 72.2 & 68.5 & 7.8 & 9.4 & 36.0 & 35.0 \\
\hline FYM+NPK & 73.4 & 96.3 & 12.2 & 13.1 & 35.6 & 35.1 \\
\hline GYPSUM + SSP & 56.3 & 68.0 & 8.3 & 10.3 & 36.3 & 33.5 \\
\hline GYPSUM + NPK & 71.5 & 79.9 & 8.9 & 11.5 & 35.5 & 36.1 \\
\hline SSP + NPK & 70.2 & 75.5 & 10.2 & 12.2 & 36.7 & 35.7 \\
\hline Untreated & 47.5 & 52.7 & 5.9 & 8.2 & 36.3 & 36.0 \\
\hline Grand Mean & 63.7 & 70.7 & 8.9 & 10.7 & 36.3 & 36.0 \\
\hline F-LSD (P = 0.05) & 1.7 & 2.3 & 1.4 & 0.4 & $\mathrm{NS}$ & NS \\
\hline SD & 8.3 & 11.8 & 1.7 & 1.6 & 0.4 & 0.9 \\
\hline CV (\%) & 13.8 & 13.8 & 6.9 & 6.9 & 1.0 & 1.0 \\
\hline
\end{tabular}

FYM = Farmyard Manure; SSP = Single Super Phosphate; NPK = NPK (15:15:15); F-LSD = Fishers Least Significant Difference; $\mathrm{SD}=$ Standard Deviation; $\mathrm{CV}=$ Coefficient of Variation.

Table 3:- Effect of Different Fertilizer Sources and Combinations on Groundnut Yield in 2016 and 2017

\begin{tabular}{|l|c|c|c|c|c|c|c|c|c|}
\hline $\begin{array}{l}\text { Fertilizer } \\
\text { Combination }\end{array}$ & $\begin{array}{c}\text { Fresh Pod Yield } \\
\text { (t/ha) }\end{array}$ & \multicolumn{2}{c|}{$\begin{array}{c}\text { Dry Pod Yield } \\
\text { (t/ha) }\end{array}$} & \multicolumn{2}{c|}{$\begin{array}{c}\text { Haulm Yield } \\
(\mathrm{t} / \mathrm{ha})\end{array}$} & \multicolumn{2}{|c|}{$\begin{array}{c}\text { Seed Weight } \\
(\mathrm{g})\end{array}$} \\
\hline & 2016 & 2017 & 2016 & 2017 & 2016 & 2017 & 2016 & 2017 \\
\hline FYM & 1.31 & 1.58 & 1.28 & 1.47 & 2.09 & 4.17 & 45.51 & 48.03 \\
\hline GYPSUM & 1.23 & 1.45 & 1.08 & 1.35 & 1.90 & 2.99 & 49.04 & 47.22 \\
\hline SSP & 1.33 & 1.52 & 1.31 & 1.43 & 1.56 & 2.71 & 48.22 & 48.01 \\
\hline NPK & 1.30 & 1.54 & 1.26 & 1.47 & 1.82 & 3.78 & 46.70 & 47.58 \\
\hline FYM + GYPSUM & 1.35 & 1.50 & 1.21 & 1.42 & 1.63 & 2.84 & 45.32 & 48.01 \\
\hline FYM+SSP & 1.44 & 1.65 & 1.38 & 1.56 & 2.31 & 4.29 & 49.02 & 47.88 \\
\hline FYM+NPK & 1.25 & 1.48 & 1.18 & 1.36 & 2.42 & 4.78 & 48.03 & 47.09 \\
\hline GYPSUM + SSP & 1.33 & 1.54 & 1.23 & 1.43 & 1.83 & 2.99 & 46.77 & 48.11 \\
\hline GYPSUM + NPK & 1.27 & 1.48 & 1.19 & 1.35 & 2.41 & 4.03 & 47.12 & 49.01 \\
\hline SSP + NPK & 1.46 & 1.71 & 1.64 & 1.66 & 2.11 & 4.03 & 45.67 & 47.23 \\
\hline Untreated & 1.07 & 1.19 & 0.81 & 1.09 & 1.33 & 2.02 & 48.31 & 47.02 \\
\hline Grand Mean & 1.30 & 1.51 & 1.27 & 1.42 & 1.95 & 3.51 & 47.24 & 47.74 \\
\hline FLSD (P=0.05) & 0.02 & 0.05 & 0.24 & 0.12 & 0.02 & 0.55 & NS & NS \\
\hline SD & 0.11 & 0.13 & 0.28 & 0.14 & 0.36 & 0.84 & 1.37 & 0.59 \\
\hline CV (\%) & 2.2 & 1.9 & 2.7 & 2.9 & 2.5 & 5.8 & 1.3 & 1.1 \\
\hline
\end{tabular}

FYM = Farmyard Manure; SSP = Single Super Phosphate; NPK = NPK (15:15:15); F-LSD = Fishers Least

Significant Difference; $\mathrm{SD}=$ Standard Deviation; $\mathrm{CV}=$ Coefficient of Variation.

\section{Discussions:-}

Aflatoxin contamination constitutes one of the most challenging problems in food safety in developing countries. This is majorly due to its health implications but also negative effect on trade across country borders. In a country like Nigeria which is the largest producer of groundnut in Africa, it is pertinent that exposure to aflatoxin contamination is highly reduced if the country must continue in exportation of groundnut and ensure the health of its citizenry. In order to curb this menace of aflatoxin, it is therefore necessary to explore options that are not only effective but also affordable to the vast majority of resource-limited farm families. 
This study focused on elucidating the effects of different fertilizer combinations on aflatoxin contamination levels on an improved high yielding, extra early maturing and rosette reistant variety groundnut variety under the Southern Guinea Agroecology of Nigeria. Of all the fertilizer sources evaluated in the study, gypsum was the most effective in reducing aflatoxin contamination. This finding corroborates previous work by Waliyar et al. (2008), who reported that the application of lime or any calcium source fertilizer alone reduced aflatoxins contamination by $72 \%$. Furthermore, the study showed that although, the application of gypsum alone reduced aflatoxin contamination levels, it did not significantly improve growth characteristics (plant height and number of branches) and yield compared to the other fertilizer combinations.

Contrastingly, the use of farmyard manure significantly increased aflatoxin contamination levels of over the two years, especially during the 2017 cropping season. In their report, Nakhro and Dkhar (2010) noted that organically treated plots recorded the maximum microbial population counts (fungal and bacterial) and microbial biomass carbon, followed by the inorganically treated plots. Similar findings were reported by Kumar et al. (2010). This study, however showed that farmyard manure significantly improved growth characteristics and biomass of groundnut. In fact, all combinations of farmyard manure such as FYM+Gypsum, FYM+NPK, FYM+SSP had higher levels of aflatoxin contamination compared to fertilizer combinations without farmyard manure with the least been FYM+Gypsum.

The use of farmyard manure is very popular among resource-limited farmers who use it as a primary source of fertilizer. The implication of such a practice as revealed by this study is that mitigating aflatoxin contamination becomes difficult (if not impossible) if this practice is not adequately controlled. Therefore, the source of fertilizer is a critical factor in groundnut production as it enhances the possibility of aflatoxin contamination. However, considering that the ultimate aim of agronomic venture is crop yield, combining gypsum with NPK, or SSP in groundnut production should be advocated. As demonstrated from this experiment, groundnut grown under these conditions had lower levels of aflatoxin contamination with a corresponding higher yield than solely gypsum-treated plots.

Levels of aflatoxin contamination was generally higher in 2017 compared to 2016; this could be linked to the higher rainfall and temperatures experienced in Benue State in 2017. It is known that Moisture content plays an important role in microbial activity in the soil. Indeed, high moisture contents enhances microbial activities and is even higher in an organically amended soil. Madge (1965) documented marked effects of moisture on the number of soil fungi. Moisture content and temperature gradients are chiefly responsible for the colonization of microorganisms (Marinari et al., 2000; Zaller and Koepke, 2004).

The Standards Organization of Nigeria (SON) sets limits on several food commodities, taking into account global standards as well as national production and target export markets. While it is generally recognized that there is no safe level of aflatoxin exposure, SON has set the maximum acceptable limit for groundnut at $4 \mathrm{ppb}$ for total aflatoxins and $2 \mathrm{ppb}$ for aflatoxin B1. Although none of the fertilizer combinations reduced contamination below levels to those stipulated by SON, groundnut grown in gypsum and gypsum-combined fertilizer treated-plots showed reduced levels. With respect to products for human consumption, the current action level is $20 \mathrm{ppb}$ total aflatoxin in finished products and findings from this study clearly showed that all gypsum-treated plots reduced aflatoxin levels below $20 \mathrm{ppb}$ and recommended for use in groundnut production systems. Nonetheless, research is still required to quantify toxigenic Aspergillus fungal population and determine optimal rates of Gypsum+NPK and Gypsum+SSP fertilizer combinations that will increase yields while reducing $\mathrm{AfB}_{1}$ contamination in groundnut.

\section{Acknowledgements:-}

This study was carried-out using funds provided by the United States Agency for International Development (USAID) within the framework of the implementation of the project dubbed "Increasing Groundnut Productivity of Smallholder Farmers in Mali, Ghana and Nigeria implemented by the International Crops Research Institute for the Semi-arid Tropics (ICRISAT). We are also grateful to Mr. P.O. Unah for his technical assistance during field operations. 


\section{References:-}

1. Ainsworth, G.C. and Austwick, P.K.C. (1973). Fungal diseases of animals. 2nd ed. Slough: Commonwealth Agricultural Bureau. Pp $36-68$.

2. Ajeigbe H.A, Waliyar F, Echekwu CA, Ayuba K, Motagi BN, Eniayeju D and Inuwa A. (2014). A Farmer's Guide to Groundnut Production in Nigeria. Patancheru 502 324, Telangana, India: International Crops Research Institute for the Semi-Arid Tropics. $36 \mathrm{pp}$.

3. Alenyorege, E.A., Abagale, F.K., Yawson, A. and Opoku, N. (2015). Effects of Fertilization on Aflatoxin Concentration in Fresh and Stored Groundnuts (Arachis hypogaea L.). International Journal of Science, Engineering and Technology Research 4(9): 3165 - 3169.

4. Anjaiah, V., Thakur, R.P. and Koedam, N. (2006). Evaluation of bacteria and Trichoderma for biocontrol of pre-harvest seed infection by Aspergillus flavus in groundnut. Biocontrol Science and Technology 16(4): 431 436.

5. Cotty, P.J. (1994). Influence of field application of an atoxigenic strain of Aspergillus flavus on the populations of A. flavus infecting cotton bolls and on the aflatoxin content of cottonseed. Phytopathology 84:1270-1277.

6. Cotty, P.J. (1999). Cardwell KF. Divergence of West African and North American Communities of Aspergillus Section Flavi. Applied Environmental Microbiology 65:2264 - 2266.

7. Hameeda, B., Rupela, O.P. and Reddy, G. (2006). Antagonistic activity of bacteria inhabiting composts against soil-borne plant pathogenic fungi. Indian Journal of Microbiology 46(4): 389 - 396.

8. Hesseltine, C.W. (1965). A millennium of fungi, food, and fermentation. Mycologia 57:149 - 97.

9. Klich, M.A., Tang, S. and Denning, D.W. (2009). Aflatoxin and ochratoxin production by Aspergillus species under ex vivo conditions. Mycopathologia 168: 185 - 191.

10. Kumar, R., Srivastava, S., Srivastava, M. and Sinha, A. (2010). Effect of Organic Amendments on Soil Mycoflora. Asian Journal of Plant Pathology 4: 73-81.

11. Madge, D.S. (1965). Leaf fall and litter disappearance in a tropical forest. Pedobiologia 5: 273 - 288.

12. Marinari, S., Masciandaro, G., Ceccanti, B. and Grero, S. (2000). Influence of organic and mineral fertilizers on soil biological and physical properties. Bioresource Technology 72: 9-17.

13. Nigam, S.N. (2002). Aflatoxin management: Host-plant resistance. In Aflatoxin detection, quantitative estimation and management. Proceedings of a Consultative Meeting, 8-9 Jan 2001, ICRISAT Patancheru. Published by Scottish Crop Research Institute, Invergowrie, Dundee, DD2 5DA, UK. P. 16

14. Nakhro, N., and Dkhar, M.S. (2010). Impact of Organic and Inorganic Fertilizers on Microbial Populations and Biomass Carbon in Paddy Field Soil. Journal of Agronomy 9: 102 - 110.

15. Ntare, B.R., Waliyar, F., Ramouch, M., Masers, E. and Ndjeungda, J. (2005). Market Prospects for Groundnut in West Africa. CFC Technical Paper no.39. Common Fund for Commodities, Amsterdam, The Netherlands.

16. Sharma, K.K., Bhatnagar-Mathur, P., Sai-Vishnu-Priya, K., Anjaiah, V., Vadez, V., Waliyar, F., Kumar, P.L., Nigam, S.N. and Hoisington, D.H. (2006). Genetic engineering of groundnut for crop improvement. In International Conference on Groundnut Aflatoxin Management and Genomics, 5 - 10 November 2006, Gungdon Hotel, Guangzhou, China. In International Conference on Groundnut Aflatoxin Management and Genomics, 5 - 10 November 2006, Gungdon Hotel, Guangzhou, China.

17. Thakur, R.P. and Waliyar, F. (2005). Biocontrol of preharvest aflatoxin contamination in groundnut. Pages 5667 in Biocontrol Research at ICRISAT: Present status and future priorities - Proceedings of the In-house Review, 5 April 2005. ICRISAT, Patancheru 502 324, Andhra Pradesh, India.

18. Uguru, M.I. (2011). Crop Production Tools, Techniques and Practice. Fulladu Publishing Company, Nsukka: Nigeria. Pp 176.

19. Upadhyaya, H.D., Nigam, S.N., and Thakur, R.P. (2002). Genetic enhancement for resistance to aflatoxin contamination in groundnut. In Summary proceedings of the seventh ICRISAT regional groundnut meeting for Western and Central Africa, 6-8 December 2000, Cotonou, Benin. ICRISAT CPE/F 142. Pages 29-36.

20. Upadhyaya, H.D., Nigam, S.N., and Waliyar, F. (2004). Aflatoxin contamination of groundnut: Coventional breeding for resistance. In Proceedings of the 3rd Fungal Genomics, 4th Fumonisin, and 16th Aflatoxin Elimination Workshops, 13-15 Oct 2003, Savannah, Georgia, USA. Page 55

21. Waliyar, F., Craufurd, P., Padmaja, K.V., Reddy, R.K., Reddy, S.V., Nigam, S.N. and Kumar, P.L. (2006). Effect of soil application of lime, crop residue and biocontrol agents on pre-harvest Aspergillus flavus infection and aflatoxin contamination in groundnut. In International Conference on Groundnut Aflatoxin Management and Genomics, 5 - 10 November 2006, Gungdon Hotel, Guangzhou, China.

22. Waliyar, F., Osiru, M., Ntare, B.R., Vijay Krishna Kumar, K., Sudini, H., Traore, A. and Diarra, B. (2015). Post-harvest management of aflatoxin contamination in groundnut. World Mycotoxin Journal 8 (2): 245 - 252. 
23. Waliyar, F., Ntare, B.R., Diallo, A.T., Kodio, O. and Diarra, B. (2007). On farm management of aflatoxin contamination of groundnut in West Africa. A synthesis report. International Crops Research Institute for the Semi-Arid Tropics, Telangana, India.

24. Waliyar, F., Kumar, P. L., Traore, A., Ntare, B. R., Diarra, B., and Kodio, O. (2008). Pre and post-harvest management of aflatoxin contamination in peanuts. In J. F. Leslie, R. Bandyopadhyay, \& A. Visconti (Eds.), Mycotoxins: Detection methods, management, public health and agricultural trade, CAB international (pp. 209218). Wallingford. doi:10.1079/9781845930820.0209

25. Waliyar, F., Osiru, M., Sudini, H. K., and Njoroge, S. (2013). Reducing aflatoxins in groundnuts through integrated management and biocontrol. In Aflatoxins: Finding solutions for improved food safety. CGIAR, IFP Focus 20: Brief 18, November 2013 Aflatoxins. Finding Solution. Retrieved from www.ifpri.org

26. Zaller, J.G. and Koepke, U. (2004). Effect of traditional and biodynamic farmyard manure amendment on yields, soil chemical, biochemical and biological properties in a long-term field experiment. Biology and Fertility of Soils 40: $222-229$. 